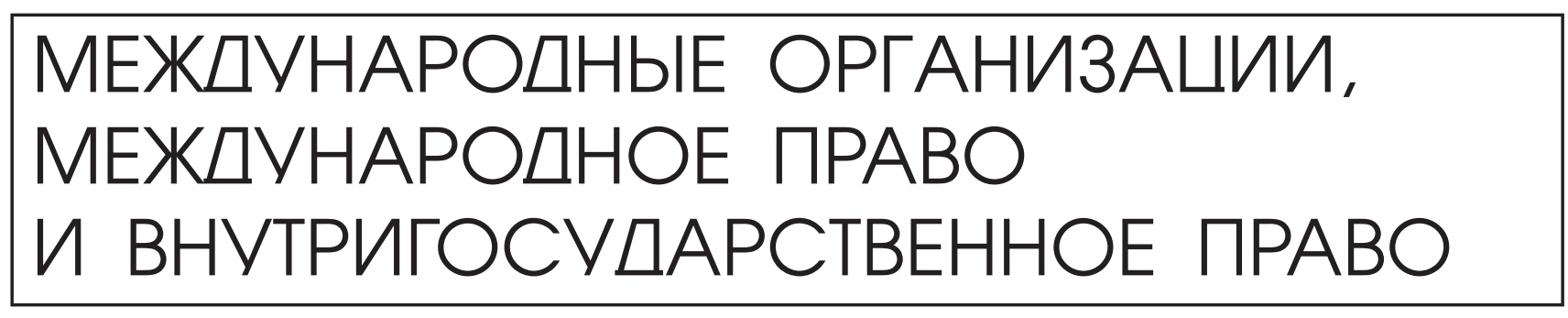

Костенко Н.И.

\title{
РОЛЬ ОРГАНИЗАЦИИ ОБЪЕДИНЕННЫХ НАЦИЙ ПО РЕШЕНИЮ ПРОБЛЕМ ПРАВОСУДИЯ ПЕРЕХОДНОГО ПЕРИОДА И ГОСПОДСТВА ПРАВА В КОНФЛИКТНЫХ И ПОСТКОНФЛИКТНЫХ ГОСУДАРСТВАХ
}

\begin{abstract}
Аннотация. Цель настоящей статьи, заострить внимание на основных вопросах, извлеченных из деятельности Организации Объединенных Наций по укреплению правосудия и утверждению приниипа господства права в конфликтных и постконфликтных субъектах за последний двадиатилетний опыт. Задачами, позволяющими её достичь, следует учитывать критический и сравнительный анализ правовой базы, а также доктринальных наработок по проблемам фундаментальных иенностей одним из поставленных задач перед мировым сообществом - реформа, поддержка и отправления правосудия, укрепление уважение к принципу верховенство права. Анализ показывает, что соблюдение законности по укреплению правосудия и утверждению принщипа господства права в конфликтных и постконфликтных субъектах за последний двадиатилетний опыт - имеет фундаментальное значение для обеспечения устойчивого мира после урегулирования конфликта, для эффективной защиты прав человека и для устойчивого экономического прогресса и развития. Такой опыт показывает, что упрочение мира непосредственно в постконфликтный период, ровно, как и поддержание мира в долгосрочной перспективе будет невозможным, если население государств не будет уверено в том, что оно может добиться возмещения причиненного ущерба при помощи легитимных структур для мирного урегулирования споров и справедливого отправления правосудия.
\end{abstract}

Ключевые слова: проблемы правосудия, поддержка правосудия, реформа правосудия, отправления правосудия, приниип верховенства права, стандарты ООН, поддержка господства права, миротворческие операции, правосудие переходного периода, Международный уголовный суд

Abstract: The goal of this article is to draw attention to the key issues regarding the activities of the United Nations Organization in the sphere of solving the problems of justice of transitional period and support of supremacy of law in conflict and post-conflict subjects in the last two decades. In order to achieve this goal the author uses critical and comparative analysis of the legal basis and doctrine in the sphere of fundamental values, which the international community now faces: reform and support of administering justice and the principle of supremacy of law. The analysis shows that compliance to lawfulness in the sphere of support of justice and supremacy of law in the conflict and post-conflict is fundamental for the guarantees of sustainable peace after resolving a conflict, and also for the efficient protection of human rights, sustainable economic progress and development. This experience shows that protection of peace both in the short-term perspective in the post-conflict period and in the long-term perspective are impossible, unless the population of the states become assured that they can achieve compensation of the harm caused to them via the legitimate structures for peaceful dispute settlement and fair administration of justice.

Keywords: problems of justice, support of justice, reform of justice, administration of justice, the principle of supremacy of law, the UN standards, support of the supremacy of law, peace-making operations, justice in the transitional period, the International Criminal Court. 


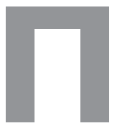
овышая эффективность Организации объединенных Наций в деле поддержания мира и безопасности путем предоставления в её распоряжение ресурсов и инструментов, необходимых ей для предотвращения конфликтов, мирного разрешения споров, проведения операций по поддержанию мира, постконфликтного миростроительства и реконструкции, Генеральная ассамблея ООН 8 сентября 2000 г. в своей декларации на новое тысячелетия посчитала, что существенное большое значение для международных отношений в XXI веке будет иметь ряд фундаментальных ценностей одним из поставленных задач - укрепление уважение к принципу верховенство права.

«Верховенство права» - это понятие, составляющее саму суть миссии Организации Объединенных Наций. Соблюдение законности имеет фундаментальное значение для обеспечения устойчивого мира после урегулирования конфликта, для эффективной защиты прав человека и для устойчивого экономического прогресса и развития. Принцип, согласно которому все - от отдельного человека вплоть до самого государства - обязаны соблюдать законы, которые были публично приняты, в равной степени исполняются и независимо реализуются судебными органами, лежит в основе концептуального подхода, в значительной степени направляющего работу Организации Объединенных Наций.

Принцип верховенства права, закрепленный в Уставе Организации Объединенных Наций, включает в себя элементы, касающиеся отношений между государствами. Основным органам Организации Объединенных Наций, включая Генеральную Ассамблею и Совет Безопасности, отводятся в этой связи ключевые функции, которые вытекают из Устава Организации и подразумевают принятие мер в соответствии с его положениями.

Думается, что для Организации Объединенных Наций верховенство права означает такой принцип управления, в соответствии с которым все учреждения и структуры, государственные и частные, в том числе само государство, функционируют под действием законов, которые были публично приняты, в равной степени исполняются и независимо реализуются судебными органами и которые совместимы с международными нормами и стандартами в области прав человека. Для этого также необходимы меры, обеспечивающие соблюдение принципов примата права, равенства перед законом, ответственности перед законом, беспристрастного применения законов, разделения властей, участия в принятии решений, правовой определенности, недопущения произвола и процессуальной и правовой транспарентности.

На этот счет Организация Объединенных Наций уделяет повышенное внимание международной уголовной юстиции, в частности проблемам правосудия и господства права. На наш взгляд, успех этой работы зависит от ряда важных факторов, включая необходимость обеспечить основу в виде международных норм. И в тоже время мобилизовать необходимые ресурсы в систему отправления правосудия. Думается, что на этот счет следует воздержаться от использования неких универсальных форм и искусственного насаждения инородных моделей, а вместо этого оказывать свою помощь на основе национального участия.

Считаю, что Организация Объединенных Наций должна поддерживать национальные идеи, продвигающие реформы в системе уголовной юстиции по вопросам правосудия переходного периода и оказывать помощь в заполнении правового вакуума, который образовался в столь многих постконфликтных субъектах.

Убежден в том, что справедливость, мир и демократия - это не взаимоисключающие цели, а, наоборот, императивы, дополняющие друг друга. И для утверждения всех этих трех идеалов во взрывоопасных постконфликтных субъектах должно быть осуществлено стратегическое планирование тех мероприятий, которые бы увязывали и выстраивали между собой реформирование правосудия в логической последовательности. Считаю, что на этот счет, в Организации Объединенных Наций подход к системе реформирования отправления правосудия должен быть всеобъемлющим с точки зрения уделения особого внимания всем взаимосвязанным институтам правосудия, а также обеспечить взаимодополняемость переходных механизмов отправления правосудия. И на этот счет задача Организации Объединенных Наций должна состоять в том, чтобы помочь в укреплении основ национальной системы юстиции.

Цель настоящей статьи, заострить внимание на основных вопросах, извлеченных из деятельности Организации Объединенных Наций по укреплению правосудия и утверждению принципа 
господства права в конфликтных и постконфликтных субъектах за последний двадцатилетний опыт. Такой опыт показывает, что упрочение мира непосредственно в постконфликтный период, ровно, как и поддержание мира в долгосрочной перспективе будет невозможным, если население государств не будет уверено в том, что оно может добиться возмещения причиненного ущерба при помощи легитимных структур для мирного урегулирования споров и справедливого отправления правосудия. В то же время повышенная уязвимость задержанных, заключенных, перемещенных, беженцев и других групп, которые имеют место во всех конфликтных и постконфликтных ситуациях, диктует необходимость безотлагательного решения таких важных задач, как восстановления господства права.

Хотелось бы обратить внимание на оказание помощи населению пережившим войну в восстановлении господства права и ликвидации последствий крупномасштабных нарушений законности, причем в условиях, когда инфраструктура разрушена, ресурсы истощены, общая ситуация остается неспокойной, а населения государства психологически травмировано и разделено, это весьма сложная задача. И в процессе её решения Организации Объединенных Наций приходилось и приходиться иметь дело с дефицитом политической воли проведению реформ, отсутствие организационной автономии у системы уголовной юстиции, слабость национальной технической базы, нехватка материальных и финансовых ресурсов, отсутствие у населения государств доверия к правительству, игнорирование прав человека официальными органами и, в более общем плане, отсутствие мира и безопасности.

Нормативной основой для рассмотрения обозначенной выше проблемы является сам Устав Организации Объединенных Наций наряду с тремя важными проблемами современной международной правовой системы: международными стандартами в области прав человека; международным гуманитарным правом и международным уголовным правом. Считаю, что сюда входит полный набор стандартов Организации Объединенных Наций в области прав человека, и они представляют собой общеприемлемые стандарты, принятые Организацией Объединенных Наций, и поэтому служат нормативной основой для всей деятельности Организации
Объединенных Наций в поддержку правосудия и господства права.

Если же обратиться к нормам и стандартам Организации Объединенных наций то они разрабатываются и принимаются всеми государствами мира и включаются в правовые системы государств-участников, независимо от того, основаны ли они на той или иной правовой системе. И благодаря этому эти нормы и стандарты обеспечивают легитимность, устанавливают нормативные границы участия Организации Объединенных Наций. И все это способствует тому, что суды, образованные под эгидой Организации Объединенных Наций не могут применять смертную казнь. В мирных соглашения, одобренных Организацией Объединенных Наций, не может быть предусмотрена амнистия за международные преступления и в тех случаях, когда учреждения, действующие под управлением Организации Объединенных Наций на осуществления судебных функций, обязаны соблюдать международные стандарты в области прав человека.

Думается, что при вынесении рекомендаций Организацией Объединенных Наций необходимо тщательно рассматривать конкретные потребности каждого принимающего государства в области обеспечения господства права и правосудия. В соответствии с этим должны быть оценены последствия мирных соглашений, касающихся господства права, и условия и характер правовой системы государства, её традиции и институты.

Необходимо отметить, что Организация Объединенных Наций не всегда предоставляла помощь по обеспечению господства права, которая бы способствовала особенностям государства. В то же время Организация Объединенных Наций на сегодняшний день уделяет большое внимание стратегиям оценки и консультаций под национальным руководством, осуществляемым при активном и существенном участии национальных заинтересованных сторон, в том числе должностных лиц сектора правосудия. И на этот счет следует отметить, что национальные органы берут на себя руководство в проведении обследования сектора правосудия путем мобилизации национальных специалистов в области права и возглавляют национальные консультации и оценки, связанные с правосудием переходного периода.

Думается, что в рамках этих процессов Организация Объединенных Наций должна оказывать помощь в проведении совещаний, консультаций по 
правовым вопросам, оставляя при этом руководство и принятия решений за национальными заинтересованными должностными лицами государства.

Считаем, что в большинстве случаев успех деятельности в области правосудия переходного периода во многом обусловлен большим числом и высоким качеством консультаций, проводимых с общественностью и жертвами преступлений. Такие консультации позволяют лучше понять динамику прошлых конфликтов, характерные черты дискриминации и мотивы совершаемых преступлений. Хочется отметить, что нельзя надеяться на успех или стабильность реформ в интересах господства права, перестройки системы правосудия, которые насаждаются извне (суд присяжных в России по американскому сценарию). Думается, что роль Организации Объединенных Наций и международного сообщества в целом должна заключаться не в подмене, а в проявлении солидарности. Принципиально важно обеспечить, чтобы эти условия были основаны на существенном участии общественности с привлечением национальных специалистов в области права, правительства, гражданского общества. Важным является то, что программы Организации Объединенных Наций по вопросам реформирования системы правосудия должны обеспечить выявление, поддержку и наделение правами национальных участников реформ. Так, например, в ходе миротворческих операций нужно лучше оказывать помощь национальным участникам в целях развития их собственного видения реформы, их собственных подходов к правосудию переходного периода. И наиболее важная роль, заключается в содействии процессам, на основе которых различные заинтересованные участники обсуждают и излагают в общих чертах элементы плана их государства по устранению и проявлений несправедливости в прошлом и обеспечению прочной справедливости в будущем, в соответствии с международными стандартами. И на этот счет международное сообщество должно уважать и поддерживать местные институты в реформе системы правосудия, оставаясь в то же время верными международным нормами и стандартам.

Думается, что поддержку реформ системы правосудия необходимо культивировать среди бывших комбатантов и (не уголовных) элементов бывших режимов, причем все они должны быть заверены в том, что они будут защищены от не- законного и несправедливого возмездия. Надо заметить, что в условиях рассмотрения процессов реформирования правосудия переходного периода одними из особенно важных участников выступают жертвы государства. На этот счет, на наш взгляд, Организация Объединенных Наций должна оценивать и уважать интересы жертв при разработке и осуществлении на практике мер в области правосудия переходного периода.

Считаем, что в эффективных стратегиях обеспечения господства права акцент должен непременно делаться на правовые институциональные потребности, должное внимание следует уделять политическим элементам. Большой интерес общественности вызывает деятельность по восстановлению систем отправления правосудия, планированию реформ системы обеспечения господства права и согласованию процессов отправления правосудия переходного периода. Полагаем, что на наш взгляд, эти вопросы являются обязательным предметом серьезных консультаций на уровне общественности и носят политический характер. Думается, что оценку деятельности учреждений, которым оказывается международная помощь, нельзя проводить с точки зрения лишь повышения ее эффективности без учета их приверженности делу обеспечения прав человека или ответственности за организуемые ими публичные дискуссии. Нам кажется, что в ряде случаев власти больше обеспокоены консолидацией власти, чем укреплением господства права, при этом последнее зачастую воспринимается как угроза для первой. Поэтому высокопоставленные представители Организации Объединенных Наций в этой области должны уделять пристальное внимание поддержке политических аспектов реформ в области систем правосудия и господства права. Нам кажется, что их добрые услуги могут иметь решающее значение для обеспечения реформаторам политического пространства, ограждения правоохранительной системы от политического насилия и мобилизации ресурсов в целях укрепления системы отправления правосудия.

Анализируя деятельность международного сообщества, можно сказать, что оно довольно часто недооценивает ту степень политической воли, которая необходима для поддержания эффективной реформы системы обеспечения господства права в постконфликтных государствах, и в тоже время не прилагает должных усилий для проведения публич- 
ных консультаций по вопросам перестройки системы правосудия. Поэтому в стратегиях, касающихся системы отправления правосудия игнорируется необходимость содействовать достижению консенсуса между основными заинтересованными сторонами в отношении создания новых институтов.

Следует отметить довольно важный факт, что реформы системы обеспечения господства права и деятельность по обеспечению отправления правосудия переходного периода нередко проводятся одновременно с выборами представителей государственной власти. Такие процессы, на наш взгляд, имеют довольно важное значение для обеспечения их успеха и легитимности. Нужно сказать, что правосудия и государственная власть - это не противоборствующие силы, а наоборот они скорее всему содействуют взаимному развитию и укрепляют друг друга.

Полагаем, это означает, что миротворческие операции Организации Объединенных Наций планируются как краткосрочные мероприятия и анализирую прошлую практику формирование системы обеспечения господства права и развития демократии, можно сказать - сам этот процесс довольно длительный. Поэтому, занимаясь стратегическим планированием, на наш взгляд, следует учитывать необходимость установления этапов и организации международной помощи, которую выполняет Организация Объединенных Наций после завершения миротворческой миссии.

Думается, что опыт Организации Объединенных Наций, подтверждает тот факт, что он лишенный согласованности к обеспечению господства права и правосудия переходного периода, и в то же время не принесет удовлетворительных результатов по случаю переживших странами ужасов войны. И на этот счет мы считаем, что эффективные стратегии обеспечения господства права и правосудия должны быть всеобъемлющими и должны быть задействованы все институты системы отправления правосудия, как правительственные, так и неправительственные. Считаем, что такие стратегические направления должны быть направлены на стандарты правосудия, нормативную базу, которые их осуществляют, контролируют, и граждане государств должны иметь к ним доступ. Эти примеры проанализированы и автором извлечены из многолетнего опыта работы Организации Объединенных Наций в рассматриваемой области. Можно сказать, что иногда международные усилия направляются на восстановление полицейских служб, практически оставляя без внимания другие направления системы обеспечения правосудия. Например, законотворческая деятельность, профилактика преступности, совершенствование судебной системы, юридическое образование, реформирование уголовно-исполнительной, прокурорской системы, защита и поддержка жертв и гражданского общества и т. д. На наш взгляд все эти направления имеют существенное значение для обеспечения господства права и правосудия и все они взаимозависимы. Полагаем, что упущения одного из указанных направлений неизбежно ведет к ослаблении других. В других же случаях международное сообщество в поспешном порядке предписывало конкретную формулу правосудия переходного периода, при этом делая акцент только на уголовном преследовании, вместо того, чтобы первым порядком дать возможность жертвам и национальным субъектам подумать и принять решения с учетом местным обычаев и особенностей субъекта международного права. Думается, что на этот счет международное сообщество должно видеть в правосудии переходного периода то, что далеко не запрещено статусом самой судебной системой. Считаем, что вызовы постконфликтных ситуаций требуют разработки подхода, разумно сочетающего разнообразие целей и направлений, включая обеспечения ответственности, поиску истины, обеспечения сохранения мира, формирование демократии и господства права.

Полагаем, что на этот счет необходимо обратить внимание на тот случай, что в постконфликтных ситуациях законодательная база имеет многочисленные признаки политических перекосов и пренебрежения, по другому, можно сказать, содержит дискриминационные элементы и довольно редко отражает требования международных стандартов в области прав человека и международного уголовного права. Например, принимаемые чрезвычайные законы в некоторых государствах, довольно часто представляют собой обычные локальные нормы. Законы, которые имеются на бумаге, о них может не знать широкая общественность, а официальные государственные лица не имеют ни возможности, ни инструментов для их функционирования. Например, национальные судебные, полицейские и пенитенциарные (тюремные) системы государств не имеют финансовых, материальных и 
людских ресурсов, необходимых для их надлежащего функционирования. Считаем, что для таких возникающих ситуаций неизменно характерны наличие большого количества оружия, преследований по признаку пола, сексуального насилия, эксплуатация детей, организованная преступность, торговля людьми, контрабанда и другие виды преступной деятельности. Полагаем, что в таких случаях организованные преступные группировки намного лучше обеспечены ресурсами, чем местные органы власти, и на много лучше вооружены, чем местные правоохранительные органы. Автор приходит к выводу, что миротворческие операции которые проводит Организация Объединенных Наций обязана помочь государствам заполнить этот вакуум в области господства права.

Следует также отметить, что действительно Организация Объединенных Наций сталкивается с определенными трудностями в проведении миротворческих операций, когда вообще отсутствуют в государствах механизмы уголовного правосудия. И в таких случаях, как видно из практики, миротворцам противостоят преступные элементы, совершающие тяжкие и особо тяжкие преступления, создавая непосредственную угрозу для населения государства и для самой миротворческой операции. Следует обратить внимание, что военные подразделения, как правило, не имеют достаточной подготовки, навыков и ресурсы для борьбы с преступными элементами. В свою же очередь гражданские компоненты миротворческих операций, включая полицию, очень медленно развертываются. Полагаем, что такое беззаконие может серьезно подорвать усилия всей миротворческой операции. Организация Объединенных Наций, с учетом указанных реалий вместе с государствами-членами обязаны переосмыслить указанные стратегии в целях заполнения вакуума в области господства права.

Необходимо обратить внимание и на такое обстоятельство, когда полицейские операции в постконфликтных ситуациях являются решающим звеном процесса обеспечения господства права, на наш взгляд, они должны кооперироваться с другими институтами государства, которые выполняют функцию системы отправления правосудия. На этот счет, расширение возможностей полиции, или миротворческих сил организации Объединенных Наций в отношении производства арестов не стоит рассматривать как фактор укрепления господства права в отсутствие нормативной базы действующей под надлежащим прокурорским надзором мест лишения свободы, в которых бы содержались арестованные, действующей судебной системы для организации законного и своевременного судебного разбирательства.

В унисон всему сказанному, международное сообщество в лице Организации Объединенных Наций предпринимало, предпринимает и должно предпринимать непосредственные шаги по защите прав человека и его безопасности в условиях, когда в результате разрушается и перестает действовать внутренняя система обеспечения господства права, думается, что в долгосрочном плане никакие специальные, временные меры никогда не смогут заменить работу национальной системы отправления правосудия. Анализируя практику Организации Объединенных Наций видно, что её учреждения на протяжении многих десятилетий оказывает помощь странам укреплять свои национальные системы отправления правосудия в соответствии с международными стандартами. В связи с эти, можно с уверенностью говорить о том, что эффективные стратегии формирования национальных систем отправления правосудия должным образом обязаны учитывать национальную правовую базу. И законодательство государств должно соответствовать международным стандартам в области прав человека и отвечать текущим потребностям и национальным особенностям конкретной страны. Считаем, что институциональным стержнем систем, опирающихся на господство права, должна быть сильная и независимая судебная система, оснащенная и подготовленная для защиты прав человека при отправлении правосудия. Считаем, что не менее важными являются институты системы отправления правосудия - полицейские службы, следственные органы, пенитенциарные системы и гильдии адвокатов, ассоциации юристов, которые должны стоять на страже прав человека, гражданина.

Сосредотачивая внимание на создании формальной системы отправления правосудия, которая функционирует эффективно и в соответствии с международными стандартами, крайне важно остановиться на функционировании дополнительных механизмов, которые успешно функционируют в соответствии с международными стандартами. Например, независимые национальные комиссии по правам человека играют жизненно важную роль 
в обеспечении ответственности, правовой помощи, урегулировании споров и защиты прав человека в переходной период. Думается, что на этот счет при отправлении правосудия и урегулировании споров необходимо должным образом учитывать местные и неформальные традиции, с тем чтобы они продолжали играть свою важную роль и осуществляли свою деятельность в соответствии, как с международными стандартами, так и с местными традициями. Считаем, что отказ от них может сделать правосудие недоступным для отдельных групп общества. Полагаем, крайне важны в этих обстоятельствах меры по обеспечению учета гендерного фактора в работе институтов системы отправления правосудия.

Следует заметить, что Организация Объединенных Наций в значительной мере поддерживает, оказывает помощь и имеет наилучший шанс с точки зрения содействия устойчивому совершенствованию системы отправления правосудия.

На этот счет, Организация Объединенных Наций учредила целый ряд специальных уголовных трибуналов или содействовала их учреждению. При этом она стремилась к достижению ряда целей, в частности предать суду ответственность за серьезные нарушения прав человека и гуманитарного права, положить конец преступлениям и не допустить повторное проявление. В то же время восстановить справедливость для жертв и их достоинство, восстановить господство права и содействовать восстановлению мира. В целях достижения этого был создан ряд институционных моделей. К ним можно отнести специализированные международные уголовные трибуналы, учрежденные Советом Безопасности в качестве вспомогательных органов Организации Объединенных Наций по бывшей Югославии (Международный уголовный трибунал по бывшей Югославии) и по Руанде (Международный уголовный трибунал по Руанде); смешанный трибунал по Сьерра-Леоне, учрежденный как суд на основе договора; смешанный трибунал по Камбодже, предложенный в соответствии с национальным законом, специально принятым в соответствии с договором; смешанный трибунал (устроенный как «суд в суду») в форме специальной камеры в Государственном суде Боснии и Герцеговины. Ныне действующая Коллегия, обладающая исключительной юрисдикцией в отношении тяжких уголовных преступлений в Тиморе-Лешти, созданная Временной администрацией Организации Объединенных Наций в Восточном Тиморе. Необходимо отметить, что международные уголовные трибуналы, Международный уголовный трибунал по бывшей Югославии и Международный уголовный трибунал по Руанде, сыграли важную роль в достижении правосудия в бывшей Югославии и Руанде. В результате их работы усилия правового характера по привлечению преступников к ответственности будет теперь легче осуществлять благодаря прояснению вопросов, как по военным преступлениям, так и преступлениям против человечности, геноцида и других тяжких преступлений.

Наиболее важным событием последних десятилетий в длительной борьбе международного сообщества по достижению прогресса в деле обеспечения правосудия и господства права стало учреждение постоянно действующего Международного уголовного суда.

Вновь образованный постоянно действующий Международный уголовный суд -1998 г. дает новую надежду на то, что борьба безнаказанностью выйдет на качественно новый уровень, и поэтому ратификация его статута все новыми государствами необходимо всячески поощрять.

На данный момент в производство Международного уголовного Суда находиться 15 дел в контексте 7 ситуаций, которые сейчас расследуются: Уганда, Демократическая Республика Конго, Центральноафриканская Республика, Дарфур (Судан), Кения, Ливия и Кот-д’Ивуар. Судьи МУС выдали 20 ордеров на арест (2 отозваны по причине смерти подозреваемых) и 9 приказов о явке. На сегодняшний день 5 лиц находятся в Центре содержания под стражей МУС, 11 подозреваемых - на свободе ${ }^{1}$.

Как уже было сказано, Международный уголовный суд-это первый постоянный, действующий на основе международного договора международный уголовный суд. Он был основан для того, чтобы положить конец безнаказанности преступников, совершающих наиболее серьезные преступления, которыми озабочено мировое сообщество. Это военные преступления, преступления против человечности, геноцид и преступления агрессии. На сегодняшний день 122 государства стали участниками Суда. Полагаем, что очень важно, чтобы

\footnotetext{
${ }^{1}$ См.: МУС. Дело № ICC-CPI-20120314-PR776.
} 
международное сообщество смогло обеспечить Международный уголовный суд ресурсами, потенциалом и поддержкой.

Совет Безопасности ООН призван, на этот счет, сыграть особую роль в этой связи, выступая в качестве органа, наделенного правом передавать вопросы на рассмотрение Международного уголовного суда, даже в тех случаях, когда затрагиваемые страны не являются государствами-участниками Статута Суда. Одним важным компонентом в системе правосудия в переходной период, в отношении которого зачастую требовалась помощь Организации Объединенных Наций, на наш взгляд, явилась проверка государственной службы на предмет выявления лиц, связанных с прошлыми преступлениями. Думается, что сами процессы проверки помогают содействовать обеспечению стабильного господства права в государствах. Например, используя законные методы, Организация Объединенных Наций в таких государствах как Боснии, Герцеговине, Косово, Либерии, Гаити и других, разрабатывала профессиональные нормы, создавала надзорные механизмы и в свою же очередь выявляла объективные и законные критерии в уличении и устранении лиц совершающих преступления, особенно в армии, судебных органах, в органах полиции, уголовно-исполнительных учреждениях.

Можно с уверенностью отметить, что правосудие в переходной период и господство права, на наш взгляд представляет собой обширные основные области, которые находятся в центре внимания Организации Объединенных Наций. Например, в 2002 г. Исполнительный комитет по вопросам мира и безопасности ООН утвердил Заключительный доклад общесистемной Целевой группы в целях рассмотрения подходов Организации Объединенных Наций к правосудию и господству права в рамках миротворческих операций ${ }^{2}$. На этот счет, Целевая группа выработала рекомендации с целью более эффективного решения вопросов господства права в рамках миротворческих операции Организации Объединенных Наций.

Анализируя формирования правосудия переходного периода и господства права в странах, пережи-

\footnotetext{
${ }^{2}$ См.: «Заключительный доклад Целевой группы Исполнительного комитета по вопросам мира и безопасности о разработке всеобъемлющих стратегий в области господства права по поддержанию мира /Документ ООН - А/55/305-S/2002/809.
}

вающих или переживших конфликт в целях укрепления поддержки Организации Объединенных Наций в комиссии по вопросам мира и безопасности необходимо проанализировать и разработать предложения по укреплению механизма системы Организации Объединенных Наций для оказания поддержки господства и правосудия переходного периода в государствах, переживающих или переживших конфликт. Считаю, что комиссии по вопросам мира и безопасности $\mathrm{OOH}$ должна разработать подходы для обеспечения того, чтобы все стратегии, программы были направленные на поддержку конституционных, судебных и законодательных реформ и способствовали господству права и правосудия в переходной период.

На этот счет, как уже упоминалось, наиболее важным событием последнего времени в длительной борьбе Организации Объединенных Наций по достижению прогресса в деле обеспечения правосудия и господства права стало учреждения 17 июля 1998 г. Международного уголовного суда. Статут Международного уголовного суда вступил в силу 1 июля 2002 г.

Международный уголовный суд (МУС), юрисдикция которого тщательно сформулирована в Римском статуте, является первым постоянным международным судом, созданным на договорной основе для содействия прекращению безнаказанности за многочисленные тяжкие преступления, совершенные в XXI веке.

МУС является самостоятельным по отношению к Организации Объединенных Наций международным органом. МУС оказывает важное содействие на потенциальных нарушителей, напоминая им о том, что безнаказанность не гарантирована, и выполняет роль катализатора в принятии национальных законов об ответственности за наиболее тяжкие международные преступления.

По состоянию на апрель 2013 года Римский статут ратифицировало 122 государства во всём мире ${ }^{3}$. Из 193 государств-членов ООН ратифицировало только 121 (острова Кука не являются членом ООН), 31 - подписали, но не ратифицировали, а 41 - вовсе не подписали.

Российская Федерация подписала Римский статут 13 сентября 2000 года, однако ещё не ратифицировала его и, таким образом, государством-участни-

\footnotetext{
${ }^{3}$ CM: http: //ru.wikipedia.org/wiki/
} 
ком Международного уголовного суда не является. При этом Россия сотрудничает с МУС и участвует в его работе в качестве наблюдателя. В то же время, мы убежден в том, что Российская Федерация - член Совета Безопасности ООН, которая еще не ратифицировала Статут, должна как можно скорее принять меры для ратификации Римского Статута.

В то же время ряд стран принципиально возражает против самой идеи МУС как ограничивающей суверенитет государств и дающей неопределённо широкие компетенции суду; среди них США, Китай, Индия, Израиль и Иран.

Самым ярым противником деятельности МУС является США. Правительство США хотя и подписало Римский статут в 2000 году, но уже в 2002 году отозвало свою подпись. Изначально, экс президент США Билл Клинтон, подписывая документ, объяснил, что США не собираются ратифицировать Римский статут, пока в полной мере воочию не ознакомятся с работой Международного уголовного суда ${ }^{4}$. В дальнейшем уже администрация экс президента США Буша-младшего под предлогом защиты своих военнослужащих полностью отказалась от участия в Римском статуте, назвав его нарушающим национальные интересы и суверенитет США. Кроме того в 2002 году был принят специальный Закон о защите американского персонала за рубежом ${ }^{5}$ который разрешил применение военной силы для освобождения любого американского гражданина либо граждан из числа союзников США, задержанных на территории какого-нибудь государства по ордеру $\mathrm{MУC}^{6}$. Также США заключили двусторонние соглашения с рядом стран, в которых обязали их не выдавать подозреваемых американских граждан Международному уголовному суду, а в случае нарушения этих договорённостей США прекратят оказывать им военную помощь и любую иную поддержку․

Рост числа государств, ратифицировавших Римский статут (1998-2013) Государства-участники, ратифицировавшие Римский статут, делятся на следующие региональные группы:

- Африканские государства;

- Азиатские государства, в том числе государства в районе Тихого океана;

\footnotetext{
${ }^{4}$ CM: http: //ru.wikipedia.org/wiki/

${ }^{5}$ См.: American Sepvice-Members.

${ }^{6}$ CM.: http: //ru.wikipedia.org/wiki/

${ }^{7}$ См.: Там же.
}

- Восточноевропейские государства;

- $\quad$ государства Латинской Америки и Карибского бассейна;

- $\quad$ Западная Европа и другие государства.

По состоянию на апрель 2013 года 34 государства-участника МУС относятся к африканским странам, 18 - к азиатским, 18 - из Восточной Европы, 27 - из Латинской Америки и Карибского бассейна и 25 - из Западной Европы и других государств ${ }^{8}$.

На этот счет считаем, что Организация Объединенных Наций должна обеспечить это новое учреждение ресурсами, потенциалом, информацией и поддержкой, тем, в чем МУС для расследования нарушений, преследования и привлечения к судебной ответственности тех, кто несет ответственность за преступления против человечества, военные преступления, геноцида и агрессии, в случаях, когда судебная система государств не могут или не хотят привлечь виновных к ответственности. На этот счет, в соответствии с Статутом МУС, Совет Безопасности ООН призван сыграть особую роль в этой связи, выступая в качестве органа, наделенного правом передавать вопросы на рассмотрения МУС, даже в тех случаях, когда затрагиваемые страны не являются государствами-участниками Статута МУС.

Другим важным механизмом решения вопроса о злоупотреблениях в области прав человека в прошлом является комиссия по установлению истины. Данная комиссия ООН является официальным, временным несудебным органам по установлению фактов, которые расследует характер злоупотребления в области прав человека или гуманитарного права, совершавшихся на протяжении нескольких десятков лет (с 1993-2013 г.). Эта комиссия применяет свой подход с учетом положения жертвы и завершает свою работу подготовкой заключительного доклада, включающего установление фактов и рекомендации. На протяжении 20 лет было Организацией объединенных Наций было создано 30 комиссий по установлению истины, в том числе в Аргентине, Чили, Южной Африке, Перу, Гане, Марокко, Сальвадоре, Гватемале, Тиморе - Лешти и Сьерра-Леоне. Комиссия в Сальвадоре, Гватемале, Тиморе - Лешти и Сьерра-Леоне. Следует заметить, что комиссии в Сальвадоре, Гватемале, Тиморе - Лешти и Сьерра-Леоне пользовались существенной помощью и поддержкой со сторо-

\footnotetext{
${ }^{8}$ CM.: http: //ru.wikipedia.org/wiki/
} 
ны Организации Объединенных Наций, а миссии Организации Объединенных Наций в Либерии и Демократической Республике Конго оказывают сегодня поддержку консультативным процессам в отношении комиссий по установлению истины в этих странах. Думается, что эти комиссии способны принести большую пользу, помогая народам на этапе после конфликта устанавливать факты в связи с прошлыми нарушениями прав человека, тем самым укрепляя режим ответственности, сохраняя доказательства, выявлять нарушителей и вносить рекомендации в отношении организационных реформ правосудия переходного периода и господства права. Такие комиссии, исходя из своей юрисдикции, могут создавать общественную платформу для того, чтобы жертвы могли прямо делиться с народом своими личными историями, и содействовать общественному обсуждению вопроса о возможных путях примирения и обеспечить в решении вопросов правосудия переходного периода и господства права в конфликтах.

Считаем, что к числу факторов, которые могут, в какой-то мере, ограничить работу комиссий, могут относиться: политическая нестабильность, слабость гражданского общества, коррумпированность системы правосудия, боязнь жертв и свидетелей давать показания, отсутствие общественной поддержки и недостаточное финансирование.

Думается, что для успешной работы комиссии должны пользоваться реальной независимостью и использовать надлежащее доверия критерии в самом процессе отбора членов. Полагаем, эффективные государственные стратегии в области информации и коммуникации имеют важное значение для удовлетворения ожиданий общественности и жертв и уровня повышения доверия и транспарентности. Считаем, что на этот счет необходимо обеспечивать учет ими гендерного фактора и интересов жертв, а также жертв дискриминации. В то же время, многие комиссии потребуют в своей работе международной поддержки, а также уважения их оперативной независимости со стороны международных партнеров.

Таким образом, правосудия в переходной период и господство права представляют собой довольно основные области, которые находятся в центре внимания Организации Объединенных Наций в течение нескольких десятилетий. Следует заметить, что этот вопрос находился и находиться на повестке дня Генеральной Ассамблеи ООН с 1993 г. в пункте дня «Укрепления законности». В Декларации тысячелетия Организации Объединенных Наций главы государств и правительств признали коллективную ответственность за то, чтобы не жалеть усилий для укрепления господства права, а также для обеспечения уважения всех международно признанных прав человека и основных свобод.

Кроме Организации Объединенных Наций в эту работу вовлечено большое число субъектов международного права. И мы считаем, что в этих обстоятельствах большое значение приобретает эффективная координация усилий.

В 2002г. Исполнительный комитет по вопросам мира и безопасности ООН утвердил Заключительный доклад общесистемной специальной Целевой группы в целях рассмотрения подходов Организации к правосудию и господства права в рамках миротворческой операции по поддержанию мира. Целевая группа выявила с точки зрения разнообразия и глубины значительный объем ресурсов и специальных знаний в вопросе господства права в системе Организации Объединенных наций, а также некоторые упущения. Целевая комиссия выработала рекомендации об оптимальных способах использования этих ресурсов и ресурсов, имеющихся вне подразделений ООН, с целью более эффективного решения вопросов господства права в рамках миротворческих операций.

Думается, что доклад Целевой группы ООН представляет собой полезный каталог ресурсов, имеющихся в системе $\mathrm{OOH}$, и уже доказывает свою ценность для координации деятельности $\mathrm{OOH}$ по рассматриваемой проблеме. Таким образом, в качестве одной их последних мер в центральных учреждениях $\mathrm{OOH}$ была создана сеть координаторов по вопросам законности в составе квалифицированных специалистов из одиннадцати департаментов и учреждений ООН в целях содействия координации вопросов господства права и усилия ООН поддержки аспектов господства права в рамках миротворческих операций.

Думается, что для решения проблем правосудия переходного периода и господства права исключительно важное значение имеет то, чтобы миссии по поддержанию мира и сама система Организации Объединенных Наций взяли на себя обязательство действовать совместно друг с другом в рамках коллективных усилий, возглавляемых ключевыми субъектами гражданского общества и 
заинтересованными правительствами. Полагаем, чтобы все субъекты действовали через общую национальную оценку потребностей и общенациональную программу в области правосудия в переходной период, реформу правосудия и укрепления господства права.

На этот счет считаем, во-первых, чтобы в резолюциях и мандатах Совета Безопасности ООН первоочередное внимание уделялось восстановлению и уважению господства права и оказание поддержки господству права и правосудию переходного периода, особенно в тех случаях, когда для осуществления судебной и прокурорской работы требуется поддержка Организации Объединенных Наций. Во-вторых, чтобы в резолюциях Совета Безопасности ООН содержалось требование о том, чтобы все судебные процессы, суды вызывали доверие, были справедливыми, отвечали признанным международным стандартам в отношении независимой и беспристрастной судебной системы и эффективности, беспристрастности и непредвзятости прокуроров, а также целостности судопроизводства. В третьих, чтобы Совет Безопасности ООН принимал резолюции в которых содержалось признание и уважение прав потерпевших и обвиняемых в соответствии с международными стандартами при уделении особого внимания группам населения, наиболее пострадавшим в результате конфликта и на решения господства права, в том числе детям, женщинам, заключенным и другим лицам, и чтобы процессуальные действия по рассмотрению ходатайств о возмещении вреда включали особые меры, предусматривающие их участие и защиту.

Что же касается системы Организации Объединённых Наций, в целях укрепления процессов формирования правосудия переходного периода и господства права в странах, переживающих или переживших конфликт, разработать следующие вопросы:

- внести свои предложения по укреплению механизмов системы Организации Объединенных Наций для оказания поддержки господства права и правосудия переходного периода в обществах, переживших и переживающих конфликт;

- разработать подходы для обеспечения того, чтобы программы и стратегии Организации Объединенных Наций были направлены на поддержку конституционных, судебных и законодательных реформ;

- обеспечить учет точек зрения специалистов в области господства права и правосудия переходного периода в стратегическом и оперативном планировании миротворческих мероприятий.

\section{Библиография:}

1. W.A. Schabas, An Introduction to the International Criminal Court, Cambridge University Press, 2004.

2. Сазонова К.Л. «Большая пятерка» и миротворческая деятельность Организации Объединенных Наций: политические и правовые вызовы и угрозы // NB: Международное право. - 2013. - 2. - C. 1 - 15. URL: http://www.e-notabene.ru/wl/article_4769.html

3. Каламкарян Р.А. Роль Международного Суда ООН в деле поддержания международного правопорядка // NB: Международное право. - 2013. - 1. - С. 184 - 214.

URL: http://www.e-notabene.ru/wl/article_690.html

4. Каламкарян Р.А. Включенность Российской Федерации в деятельность Международного Суда ООН в деле обеспечения международной законности и правопорядка // NB: Международное право. - 2013. - 2. - C. 85 - 118. URL: http://www.e-notabene.ru/wl/article_691.html

\section{References (transliteration):}

1. W.A. Schabas, An Introduction to the International Criminal Court, Cambridge University Press, 2004.

2. Sazonova K.L. «Bol'shaya pyaterka» i mirotvorcheskaya deyatel'nost' Organizatsii Ob"'edinennykh Natsii: politicheskie i pravovye vyzovy i ugrozy // NB: Mezhdunarodnoe pravo. - 2013. - 2. - C. 1 - 15. URL: http://www.e-notabene.ru/wl/article_4769.html 
DOI: $10.7256 / 2226-6305.2013 .4 .10012$

При цитировании этой статьи сноска на dоі обязательна

Международные организации, международное право и внутригосударственное право / International organizations, international law and national law

3. Kalamkaryan R.A. Rol' Mezhdunarodnogo Suda OON v dele podderzhaniya mezhdunarodnogo pravoporyadka // NB: Mezhdunarodnoe pravo. - 2013. - 1. - C. $184-214$.

URL: http://www.e-notabene.ru/wl/article_690.html

4. Kalamkaryan R.A. Vklyuchennost' Rossiiskoi Federatsii v deyatel'nost' Mezhdunarodnogo Suda OON v dele obespecheniya mezhdunarodnoi zakonnosti i pravoporyadka // NB: Mezhdunarodnoe pravo. - 2013. - 2. - C. 85 - 118. URL: http://www.e-notabene.ru/wl/article_691.html 